\title{
Recent developments in the application of oil palm fibers in cement composites
}

\author{
Emmanuel Owoichoechi MOMOH, Adelaja Israel OSOFERO* \\ School of Engineering, University of Aberdeen, Aberdeen, AB24 3UE, UK \\ *Corresponding author.E-mail: aiosofero@abdn.ac.uk
}

(C) The Author(s) 2019. This article is published with open access at link.springer.com and journal.hep.com.cn

\begin{abstract}
Fibers obtained from different parts of the oil palm tree (Elaeis guineensis) have been under investigation for possible use in construction. Studies have been carried out investigating the engineering properties and possible applications of these fibers. However, the experimental methods employed and the values of mechanical and physical properties recorded by various authors are inconsistent. It has therefore become necessary to organize information which would be useful in the design of oil palm fiber cement composites and help researchers and engineers make informed decisions in further research and application. This review provides information about fibers from different parts of the oil palm, their properties, enhancement techniques, current and potential application in cement composites.
\end{abstract}

KEYWORDS broom, cement composite, concrete, oil palm fiber, Natural fiber-concrete, sustainability

\section{Introduction}

Cement composites are usually mixture of cement, aggregate, water, and (occasionally) additives. Concrete for example is very brittle and therefore performs poorly in tension. The need to overcome this deficiency has resulted in the incorporation of several materials to introduce ductility and produce a more durable composite. The most popular among these materials is steel, which is ductile and usually used as primary reinforcement. Steel fibers are also sometimes used as secondary reinforcement in reinforced concrete. In whatever form the reinforcing materials come, the aim of their incorporation in concrete is to improve ductility and prevent brittle failure. Aside steel, other materials used to enhance concrete ductility come in the form of fibers and are usually randomly distributed in the concrete matrix.

The continuous increase in cost, energy demands and environmental impact of infrastructure has however necessitated the need for alternatives to conventional structural reinforcements like steel. Although steel has numerous advantages when used in cement composites, it is both expensive and environmentally unsustainable. This is not the case with fibers of vegetative origins. These

Article history: Received Aug 5, 2018; Accepted Dec 15, 2018 fibers are readily available, considerably more economical to process and environmentally friendly. Use of sustainable materials in the construction industry has been a key focus of engineers, researchers, and scientists [1-8]. Several advantages of using natural fibers for cement composites have been reported in literature. Some of these advantages include; low-cost, zero-carbon footprint, light-weightiness, toughness, biodegradability, non-toxicity to the ecosystem, thermal insulation, improved acoustic insulation and high recyclability [8-17].

According to Balasubramanian and Selvan [1], the use of natural vegetable fibers in cement composites gives $10 \%$ reduction in weight, $80 \%$ reduction in energy required for production, and 5\% reduction in cost of component used when compared to a fiber-glass reinforced component. However, studies have also pointed out some disadvantages of incorporating natural vegetable fibers in concrete. Most natural vegetable fibers have high water absorption capacity resulting in poor workability in fresh concrete, degrade in alkaline environment, and as a consequence, reduce desirable properties like tensile and bond strengths [9,18-21]. Several treatments for these fibers, with the potential of negating the drawbacks have however been reported [6,7,9,22-28]. It has also been argued that the high water absorption of natural vegetable fibers can be beneficial for internal curing of the composite [29,30]. For 
non-toxicity, Lertwattanaruk and Suntijitto [31] reported that the use of natural vegetable fibers-reinforced cement composites instead of asbestos cement composites, would eliminate the risks of exposure of human lives to diseases such as asbestosis, cancer, malignant pleural disease and tumors. On these health grounds, some countries have legislated against the use of asbestos [32]. The study also highlighted that the procedure for obtaining natural vegetable fibers is pollution free and environmentally sustainable. Due to their availability across the world, fibers domiciled in any region can be enhanced to suit applications for that climate thereby reducing material import $[8,33]$.

The oil palm tree is a huge source of natural vegetable fibers. The study by Abu et al. [34] revealed that in developing countries, there have been disposal problems with fibers of the oil palm origin. These fibers are either byproducts of the process of extracting palm oil from palm fruit, cultivation activities or remains of the trees at the end of their useful life. The wastes are usually disposed indiscriminately or used by the locals as cooking fuel, both of which are not environmentally friendly. The Food and Agriculture Organization (FAO) publication on global agriculture toward 2050 [35] estimates that the world's population shall grow by over 2.3 billion people (i.e., over a third of the current population) by the year 2050 and much of this growth is expected to occur in the developing world. This means that agricultural activities will also experience an increase. One of the implications of this, aside the anticipated increase in agricultural wastes [16$36]$, is the expected pressure on already-scarce infrastructure and hence the need to provide low cost housing by governments of these developing nations for the teeming population $[9,13,33,37]$. For instance, it is deduced from the work by Taiwo et al. [38] that total oil palm wastes worldwide which presently stands as 83 million tonnes per year (dry weight) is projected to experience a $40 \%$ rise by the year 2020 .

Although, the earliest record of investigation into reinforcing concrete with oil palm fibers (OPF) was in the 1980s [1], it has recently attracted interest due to increasing level of awareness of the importance of environmental sustainability. Fibers obtained from all parts of the oil palm have been investigated for possible use in construction [24,37-47] and previous studies have carried out investigations on the engineering properties and possible applications of these fibers [20,39-41,48-56]. However, there have been inconsistencies in the experimental methods employed, and values reported in various studies on properties of the fiber. It is therefore necessary to organize information which would be useful in future research and design of oil palm fiber-cement composites. This will also aid researchers in making informed decisions when investigating the use of the fibers in construction. Consequently, a review of the applications of oil palm fibers in cement composites, from several studies is presented.

Section 1 of this article, presents an overview of natural fibers, OPFs and the justification for the review. Section 2 reviews the different types of OPFs individually; their extraction methods, chemical and mechanical properties, fiber enhancement methods and application of the fibers in cement composites. Section 3 presents a summary of findings on the inclusion of OPF in cement composites. This review is finally concluded in Section 4.

\section{Oil palm tree: Structure and fibers}

The oil palm tree is a monocotyledon [57] and grown in 3 continents (Asia, Africa, and South America) on approximately 11 million hectares of land in about 42 countries around the world. Its average lifespan of between 25 and 30 years, makes the oil palm tree the highest yielding edible oil crop in the world [24,26,58]. Malaysia and Indonesia which are the largest palm-oil producers in the world, currently face difficulties with the management of the waste generated from both oil palm cultivation and processing activities [57].

According to Dungani et al. [57], oil palm wastes from plantation sites include, oil palm shell, empty fruit bunch fiber (EFBF), oil palm pressed fruit (or mesocarp) fiber (OPMF), oil palm trunk fibers (OPTF), and oil palm frond fibers (OPFF). Oil palm broom fiber (OPBF) was mentioned for the first time in the work of Momoh and Dahunsi [37]. In oil palm fibers, the cellulose and the hemicellulose are bonded in a lignin matrix like most natural fibers. They can therefore be referred to as lignocellulosic fibers. Other chemical constituents of oil palm fibers include cellulose, hollocellulose, and ash [59]. Figure 1 illustrates the 5 types of oil palm fibers (OPF) obtainable and what part of the oil palm tree they are extracted from.

The different types of oil palm fibers (OPF) are discussed in the following sections.

\subsection{Empty fruit bunch fibers (EFBF)}

The EFBF are the fiber residues after the removal of the fruit and processing of oil from the fruit bunch. It is worthy to note that this fiber is different from the fruit fibers (OPMF) even though some studies assumed otherwise and the fiber properties reported may be misleading for engineers wishing to employ them in construction. Sreekala et al. [44] in their study used empty fruit bunch fibers (EFBF) as a combination of the bunch fibers and the fruit fibers. The study reported an average yield of $400 \mathrm{~g}$ of EFBF per fruit bunch. About 12 million tonnes of this bunch are left to be discarded yearly from palm oil refineries [58]. Kelly-Yong et al. [60] reported 4.4 tonnes of EFBF per hectare per year, as waste from oil palm refineries. They were either discarded as waste $[11,43]$, or 


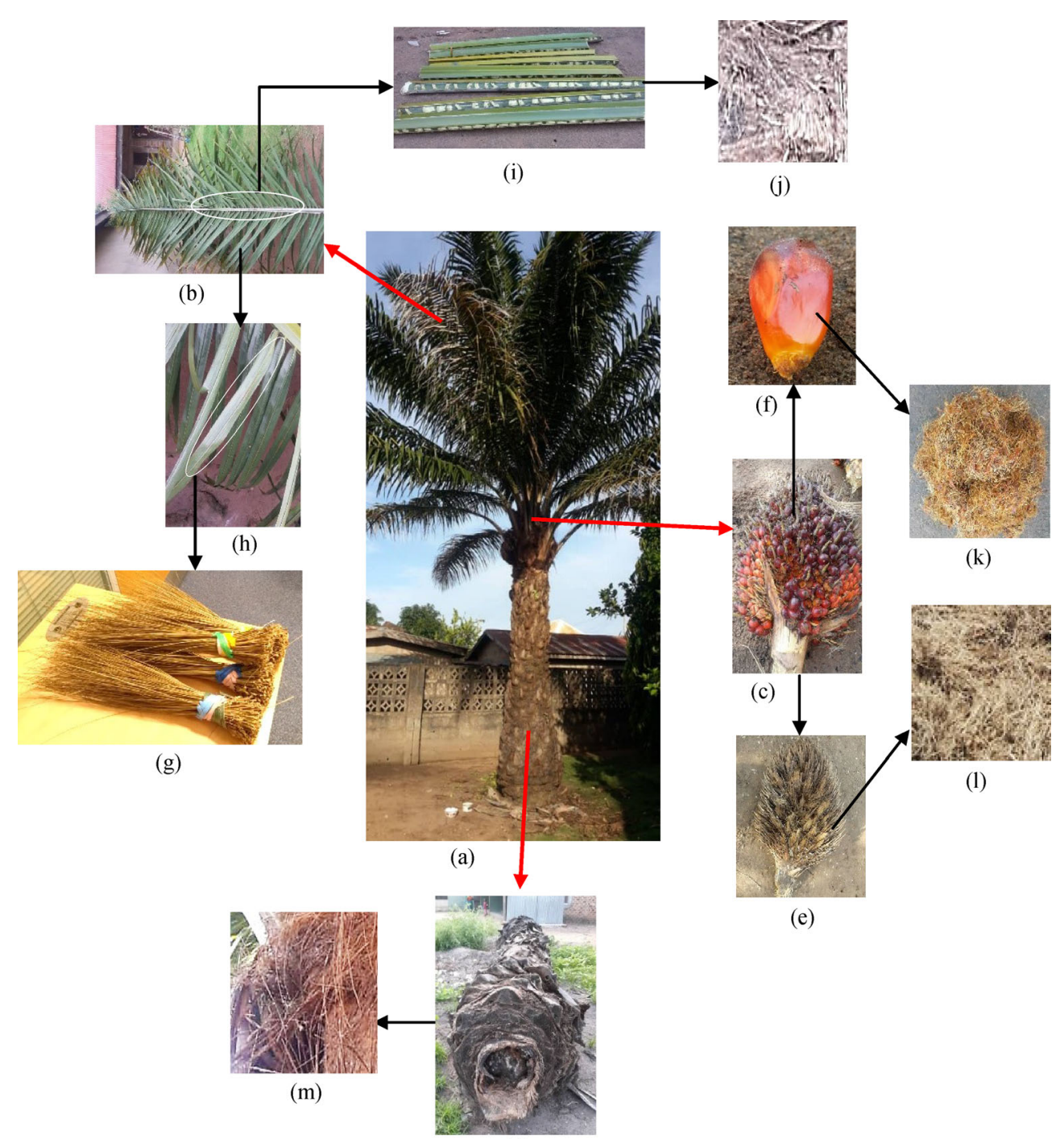

(d)

Fig. 1 Different types of oil palm fibers (OPF): (a) oil palm tree; (b) leaf; (c) fruit; (d) trunk; (e) empty fruit bunch; (f) dissected oil palm fruit; (g) oil palm broom fibers (OPBF); (h) oil palm leaflet; (i) oil palm frond; (j) oil palm frond fibers (OPFF); (k) oil palm mesocarp fibers (OPMF); (l) empty fruit bunch fibers (EFBF); (m) oil palm trunk fibers (OPTF).

used as fuel in boilers for the generation of electricity for the oil palm plantation mills. Other uses of the fiber include, manure, mulching [26], and recently in polymer composites [42,61-64].

\subsubsection{Extraction}

EFBF is extracted by retting which could be mechanical (by hammering), chemical (by immersion and boiling in chemicals), steam retting or microbial retting [26]. It is obvious however that the mechanical retting process is the most environmentally friendly as the other retting processes could lead to pollution of water bodies [24]. After palm oil is obtained by crushing the fruit bunches and fruit shells and husks, they are sieved to reduce impurities and then loosened up, washed, dried, and cut into the required lengths [54]. Jayashree et al. [65], developed a decorticating machine for EFBF extraction. The decorticator separates the fibers through the beating action of the blades. Details of this machine and its workings can be found in Jayashree et al. [65].

\subsubsection{Chemical composition}

The main constituents of OPF are cellulose, hemicellulose, hollocellulose, lignin, and ash [59]. According to Sreekala et al. [44], the EFBF have percentage compositions of lignin $(19 \%)$, cellulose $(65 \%)$, and ash $(2 \%)$ while the OPMF have lignin $(11 \%)$, cellulose $(60 \%)$, and ash $(3 \%)$. According to the research, the fibers do not contain hemicellulose which disagrees with the findings of other studies $[35,56,58,64,65]$. Based on these values however, 
it may seem reasonable to classify the mesocarp fibers as an EFBF. Table 1 shows the chemical composition of EFBF as reported in literature.

Table 1 Composition (in percentage dry weight) of oil palm empty fruit bunch fibers (EFBF)

\begin{tabular}{lcccccccc}
\hline composition & \multicolumn{7}{c}{ percentage } \\
\cline { 2 - 9 } & {$[31]$} & {$[52]$} & {$[36]$} & {$[43]$} & {$[11]$} & {$[66]$} & {$[67]$} & {$[58]$} \\
\hline Cellulose & - & 0.62 & 65 & 38.3 & 59 & - & - & $43-65$ \\
Hemicellulose & - & & - & 35.3 & 2.1 & 24.0 & 20.8 & $17-33$ \\
Holocellulose & 47.7 & - & - & - & - & 65.5 & - & $68-86$ \\
Lignin & 24.5 & 58.8 & 19 & 22.1 & 25 & 21.2 & 28.5 & $13-37$ \\
Ash & 6.99 & - & 2 & 1.6 & 3.2 & 3.5 & 5.6 & $1-6$ \\
\hline
\end{tabular}

From Table 1, it is seen that even though Abdul Khalil et al. [58] attempted to capture chemical composition of EFBF within a range, there are still discrepancies with the values reported by other researchers.

\subsubsection{Fiber treatments/enhancements}

Sreekala et al. [44] reported several treatments for enhancing the strength of EFBF. Notable among them are alkalisation, acetylation, and silane treatments for EFBF. For alkali treatment, the fibers were soaked in a solution of $5 \% \mathrm{NaOH}$ for $48 \mathrm{~h}$, then washed with fresh water and dried. There was significant reduction in crosssectional diameter for both EFBF and OPMF as a result of this treatment. Silane treatment caused 6\%-7\% weight loss in the fibers and increased the hydrophobicity of the fiber through a protective monolayer formed on proton-bearing surfaces, thereby reducing water absorption. Silane treatment was recommended for fiber surface treatment if hydrophobicity of fiber is mostly desired.

Thermal degradation is another drawback with natural vegetable fibers. Lignin, the binding agent for cellulosic fibers, begins to dissolve, at temperatures above $70^{\circ} \mathrm{C}[31]$. Under $100^{\circ} \mathrm{C}, \mathrm{EFBF}$ lost $5 \%-8 \%$ of their weight [44]. The alkali-treated fiber had a raised initial degradation temperature of $350^{\circ} \mathrm{C}$ as against $325^{\circ} \mathrm{C}$ for the untreated and acetylated fibers. Table 2 presents weight loss of untreated and treated EFBF, at varying temperatures in the thermogravimetric analysis (TGA) by Sreekala et al. [44]. A similar TGA analysis was carried out by Norul Izani et al. [68]. The TGA graph by Norul Izani et al. [68] showed that rapid thermal degradation EFBF occur beyond $250^{\circ} \mathrm{C}$ while Sreekala et al. [44] reports this temperature as $300^{\circ} \mathrm{C}$. Norul Izani et al. [68] carried out boiling of the fibers in water at $100^{\circ} \mathrm{C}$ (for $30 \mathrm{~min}$ ) and a combination of boiling and alkali treatment in a bid to enhance fiber mechanical properties. It was reported in the study that boiling does not show any marked improvements while a combination of water-boiling and alkali treatment led to
Table 2 Weight loss of treated and untreated EFBF at various temperatures [44]

\begin{tabular}{lcccc}
\hline weight loss & untreated & alkali-treated & acetylated & silane-treated \\
\hline $10 \%$ & 150 & 235 & 145 & 180 \\
$20 \%$ & 260 & 290 & 240 & 300 \\
$30 \%$ & 300 & 325 & 285 & 328 \\
$40 \%$ & 315 & 350 & 308 & 360 \\
$50 \%$ & 340 & 352 & 325 & 370 \\
$60 \%$ & 340 & 352 & 338 & 370 \\
$70 \%$ & 345 & 360 & 340 & 370 \\
$80 \%$ & 395 & 415 & 370 & 420 \\
$90 \%$ & 440 & 460 & 435 & 440 \\
$100 \%$ & 480 & 510 & 495 & 520 \\
\hline
\end{tabular}

damage of fiber surface. Although the treatments were carried out for strength enhancements of EFBF for polymeric matrices, fibers meant to be included in cement composites can be treated similarly.

Degradation at elevated temperature is synonymous with strength loss and this may not be a good indicator for structural resilience against fire. Structural elements incorporating this fiber might be susceptible to brittle failure in fire.

According to Sreekala et al. [44], Alkali-treatment causes the removal of hemicellulose, lignin and waxes, thereby increasing pore sizes on the surface of the fibers (from 0.07 to $0.15 \mu \mathrm{m}$ ) and a resulting rough surface topography. The resulting rough surface topography could enhance fiber-to-microaggregate bonding in cement composites. Fatra et al. [69] further explained this phenomenon by stating that a pectinolytic community of bacteria develops as a result of the treatment and degrades the pectin which is the main cementing part of the hemicellulose that binds the fiber together. This should result in reduced mechanical properties as corroborated in Nishiyama and Okano [70] and Beckermann et al. [71] who stated that alkali-treatment degrades cellulose chain in the fibers. Furthermore, the study by Machaka et al. [27] on the alkali treatment of fan palm fibers for inclusion in concrete, reported a reduction of $23 \%-30 \%$ of the fiber thickness due to alkali reaction. They recommended a $4 \%$ $\mathrm{NaOH}$ concentration as optimum as higher concentrations of $\mathrm{NaOH}$ led to fiber deterioration and up to $50 \%$ loss in tensile strength.

However, Norul Izani et al. [68] reported a 23\% and $14.8 \%$ increase in tensile strength and Young's modulus, respectively, after soaking the fibers in $2 \% \mathrm{NaOH}$ solution at room temperature for $30 \mathrm{~min}$. Alkali treatment is reported in Ozerkan et al. [28] as the most effective and preferred treatment against thermal degradation of OPF. Therefore, in the likelihood of exposure of OPF-reinforced cement composite to fire, OPFs could be alkali-treated 
prior to inclusion in the cement-based composites.

Ozerkan et al. [28] in comparing $\mathrm{NaOH}$ and $\mathrm{Ca}(\mathrm{OH})_{2}$ for oil palm fiber treatment, recommended $0.173 \% \mathrm{Ca}(\mathrm{OH})_{2}$ solution for alkali-treatment of date palm fibers to be incorporated in cement mortars.

Figure 2 presents scanning electron micrographs showing the effect of various treatment types on fiber surfaces.

Although the fiber treatments shown in Fig. 2 are intended for the inclusion of EFBF in the manufacture of agglomerated fiberboards and not for use in cement composites, the results corroborate the findings by Norul Izani et al. [68], Machaka et al. [27], and Ozerkan et al. [28] all of who reported improved mechanical properties of EFBF fibers treated with Alkali.

\subsubsection{Mechanical properties}

According to Sreekala et al. [44], EFBF diameter range from $0.015 \times 10^{4}$ to $0.05 \times 10^{4} \mu \mathrm{m}$ while fiber density is in the range of 700 to $1550 \mathrm{~kg} / \mathrm{m}^{3}$. These range of values lead to a large variation of mechanical properties in oil palm fiber-cement composites. Fiber treatment had no impact on the elongation of the fibers which was about $14 \%$ for the EFBF and $17 \%$ for OPMF. This strain result did not agree with the results of Shareef and Ramli [40] and Ismail and Yaacob [11] with untreated fibers strains of $4 \%$ and $30 \%$, respectively. Silane treatment enhanced the tensile strength of OPMF and EFBF by $38.8 \%$ and $10 \%$, respectively [44]. Table 3 shows some physical and mechanical properties of EFBF according to literature.

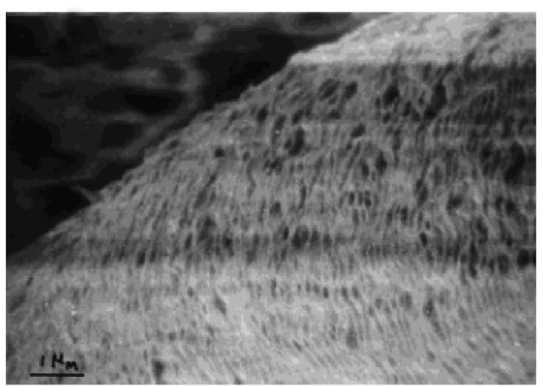

(a)

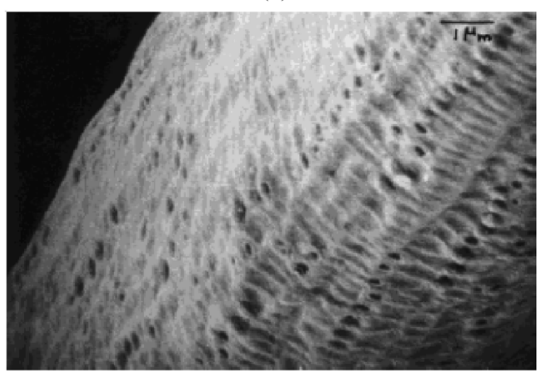

(c)

\subsubsection{Empty fruit bunch fibers (EFBF) in cement} composites

Mayowa and Chinwuba [52], studied the effect of EFBF inclusion on the compressive strength of cement mortar of mix 1:6. They recommended an optimum EFBF content of $0.6 \%$ after varying fiber inclusion (in the mortar) between $0.2 \%$ and $1 \%$ of the total cement volume. A $23 \%$ increase in compressive strength at 7 days was reduced to $10 \%$ at 28 days. The reduction in the compressive strength of the mortar with age can be attributed to a variety of factors such as, moisture-induced dimensional instability of EFBF and/or the corrosive effect of the surrounding cementitious matrix. The resulting mortar was however reported to be self-compacting and hence makes it a probable choice in the repair and retrofitting of concrete structures. The average fiber length in the study was $12 \mathrm{~mm}$.

Kaliwon et al. [41] used EFBF to reinforce concrete roof slates. The fibers were included at $0.5 \%$ and $1 \%$ of total cement volume. Though the density and flexural strength reduced with increase in percentage fiber content, flexural strength of the roof slates for $1 \%$ EFBF inclusion exceeded the ASTM requirement of $4 \mathrm{MPa}$. This corroborates the findings of Shareef and Ramli [40] who reported a $15.1 \%$ and $16 \%$ increase in compressive strength and flexural strength respectively using $1 \%$ fiber inclusion by volume.

Ismail and Hashim [73] also incorporated EFBF into concrete. The study revealed an optimum fiber volume and length of $0.5 \%$ and $5 \mathrm{~cm}$, respectively. Longer fibers were reported to create balling effects in the concrete and made mixing difficult. Strength increase of $39 \%$ was also

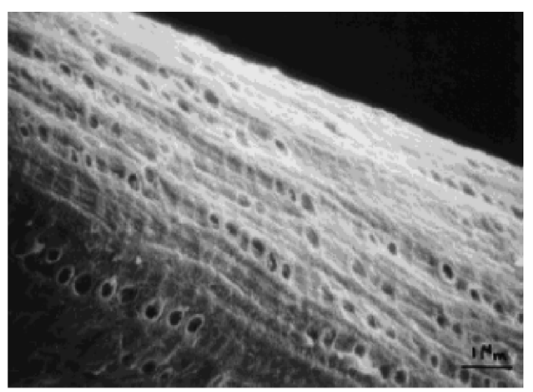

(b)

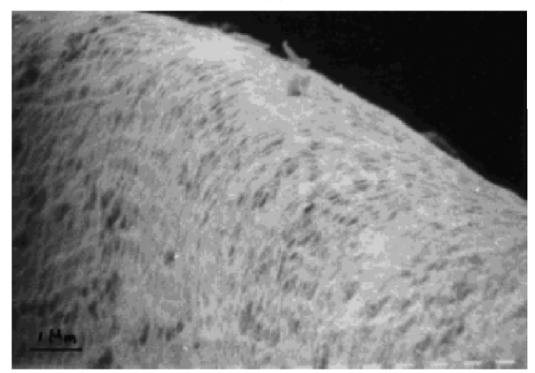

(d)

Fig. 2 Scanning Electron Microscopy (SEM) micrographs analyzing EFBF surface modifications by different methods (magnification $\times$ 400) [44]. (a) Untreated; (b) alkali-treated; (c) acetylated; (d) silane-treated. 
Table 3 Some physical and mechanical properties of EFBF

\begin{tabular}{|c|c|c|c|c|c|c|c|c|}
\hline \multirow[t]{2}{*}{ fiber properties } & \multicolumn{8}{|c|}{ value } \\
\hline & {$[45]$} & [39] & [11] & {$[58]$} & {$[43]$} & {$[54]$} & [26] & [72] \\
\hline diameter $(\mathrm{mm})$ & 0.23 & 0.02 & $0.25-0.6$ & $0.008-0.3$ & - & $0.02-0.07$ & $0.15-0.5$ & 0.35 \\
\hline length $(\mathrm{mm})$ & 17 & 30 & $100-280$ & $0.89-142$ & - & - & - & 20 \\
\hline density $\left(\mathrm{g} / \mathrm{cm}^{3}\right)$ & 4.0 & - & 1.3 & $0.7-1.55$ & - & 1.03 & $0.7-1.55$ & - \\
\hline moisture content $(\%)$ & 4.0 & - & 11 & - & - & - & - & - \\
\hline 24 hours water absorption (\%) & - & 0.6 & - & - & - & 60 & - & - \\
\hline specific gravity & - & 2.14 & - & - & - & - & - & - \\
\hline breaking elongation (\%) & - & 4 & 30 & $2.5-18$ & 14 & - & $4-18$ & $0.3-16.2$ \\
\hline tensile strength (MPa) & 19 & 21.2 & 21 & $50-400$ & 248 & - & $50-500$ & $50-55$ \\
\hline Young's modulus (GPa) & 12 & $0.5-2$ & - & $0.57-9$ & 2.0 & - & $0.6-9$ & $0.57-0.59$ \\
\hline
\end{tabular}

recorded. The result from this study agrees with that of Musa et al. [74] who recommended fiber volume of less than $1 \%$ for control of shrinkage cracking in concrete. The study also recommended $2 \%$ fiber volume for structural elements that require enhanced energy absorption from dynamic loads. Compressive and flexural strength were enhanced by up to $39 \%$. Optimum fiber length was reported as $3 \mathrm{~cm}$.

A comparison of water absorption characteristics between coconut, sugarcane bagasse and EFBF from the study showed minimal water absorption for EFBF [45]. This could be an indication of better bonding for EFBF fibers in cementitious matrices.

\subsection{Oil palm trunk fibers (OPTF)}

About 7 million tonnes of oil palm trunks are fell yearly in Malaysia alone to pave way for new plantings. At the end of their useful lifespan (25-30 years), the trees are fallen and the trunks usually left in the field to rot [53]. The crosssectional diameter of the trunks, range between 450 to $650 \mathrm{~mm}$ and usually, 7-13 $\mathrm{m}$ in length [75]. While Dungani et al. [57], reports that the oil palm biomass residue with the greatest potential for commercial exploitation is oil palm trunk, Saka et al. [76] opined that the cell density of the trunk is not consistent and possess low cellulose; hence, it is not suitable for application as a structural material. The review also reported 3 main constituents of oil palm trunk as the vascular bundles, parenchyma cells and the fibers (here-in referred to as OPTF). Available data in literature on the physical and mechanical properties of OPTF is limited. Table 4 shows some physical and mechanical properties of OPTF found in literature.

\subsubsection{Extraction}

Saka et al. [76] recommended trees of 20-30 years of age for extraction of trunk fibers. The matured trees were fallen
Table 4 Summary of physical and mechanical properties of OPTF available in literature

\begin{tabular}{lcccccc}
\hline properties & \multicolumn{7}{c}{ value } \\
\cline { 2 - 7 } & {$[53]$} & {$[74]$} & {$[75]$} & {$[76]$} & {$[57]$} & {$[77]$} \\
\hline diameter $(\mathrm{mm})$ & - & $0.3-0.6$ & - & - & 0.0261 & - \\
length $(\mathrm{mm})$ & - & - & - & - & 2.04 & - \\
density $\left(\mathrm{g} / \mathrm{cm}^{3}\right)$ & 1.2 & 1.1 & 1.2 & 0.34 & $0.2-0.6$ & - \\
moisture content & - & - & - & - & - & $2.3 \%$ \\
tensile strength $(\mathrm{MPa})$ & $300-600$ & - & - & - & - & - \\
Young's modulus (GPa) & $15-32$ & - & - & - & 3.0 & - \\
\hline
\end{tabular}

by hand or through mechanical excavator and cut into lengths of about $1 \mathrm{~m}$. Similar to EFBF extraction, the process employed in the study was mechanical beating and retting after which the fibers were washed to remove parenchyma and other impurities. The trunks were left for about 3 days to dry naturally. The dried fibers were pulled out manually with local implements and cut into required lengths of about $20-30 \mathrm{~mm}$. They were then boiled in a solution of $\mathrm{NaCl}$ and oven-dried for $24 \mathrm{~h}$ at $45^{\circ} \mathrm{C}$ [81]. The study recommended that fibers need to undergo some form of chemical treatment to improve their strength and compatibility with cement matrix.

\subsubsection{Fiber treatments/enhancements}

According to Choowang and Hiziroglu [79], OPTF has low density and high porosity which limits its usage for structural application. This however was reported to be improved by thermal compression. The samples were compressed at $140^{\circ} \mathrm{C}, 180^{\circ} \mathrm{C}$, and $220^{\circ} \mathrm{C}$ with $2 \mathrm{MPa}$ pressure for $8 \mathrm{~min}$. This caused up to $110 \%$ increase in oven-dry density of the fibers. Beyond $220^{\circ} \mathrm{C}$, the tensile strength of the fibers began to decrease. Optimum temperature of pressing the fibers was reported as $140^{\circ} \mathrm{C}$ with a $120 \%$ increase in flexural strength and $315 \%$ 
increase in modulus of elasticity. These improvements were linked to the densification of the fibers [79]. The drawback, however, was the resulting smooth fiber which may not be desirable for fiber-matrix bonding.

\subsubsection{Chemical composition}

There is a lot of variation in values of the chemical composition of OPTF reported in literature. Abdul Khalil et al. [58], in their review, attempted to put the values of each chemical compound contained in OPTF in a range, however, values recorded in other studies $[25,36,53,60,66,79]$ were outside this range. This variation in values can be attributed to factors such as, climate where the oil palm is domiciled, the age of the fibers, the extraction method, the experimental method employed, level of expertise and the efficiency of the apparatus employed. Table 5 presents a summary of the chemical composition of OPTF found in literature.

\subsubsection{OPTF in cement composites}

The potential of oil palm stem (trunk) as main reinforcement for concrete beams was investigated by Obilade and Olutoge [39]. OPTF possesses high tensile strength in the range of $300-600 \mathrm{MPa}[23,31,38]$ which is more than double the tensile strength of EFBF fibers reported by Sreekala et al. [44]. With this range of tensile strength, the trunk fibers were found to have the potential for concrete reinforcement. The study further revealed that at $1 \%$ volume addition of OPTF, the hardened concrete showed better resistance against $\mathrm{NaOH}$ and $\mathrm{NaCl}$ attack. The addition of the trunk fibers reduced the workability of fresh concrete due to an increased surface area, and increased water absorption by the fibers, thereby making less water available to the concrete [77]. Flexural strength of concrete incorporating $1 \%$ of the fiber increased by $220 \%$ while tensile strength increased by $130 \%$. Determination of tensile strength carried out in accordance to recommendations in ACI 544.1R. The work of Ahmad et al. [46] however disagrees with Ahmad et al. [77] about the optimum fiber volume of $1 \%$. Other factors like fiber length, fiber moisture content, fiber water absorption and mixing method need be investigated before conclusions on optimum fiber volume can be made. From the study, compressive strength and flexural strength of concrete incorporating $1 \%$ OPTF improved by $13.22 \%$ and $18.35 \%$, respectively.

Ahmad et al. [53] opined that the dominant failure mode of OPTF-reinforced concrete is fiber-pull-out as a result of the poor bond between fibers and surrounding concrete matrix. This agrees with the conclusion by Wei and Meyer [23]. Their study also examined the level of deterioration of OPTF-reinforced concrete by exposing specimen with $1 \%-3 \%$ OPTF content to Hydrochloric acid, $\mathrm{NaOH}, \mathrm{NaCl}$, and water. It was observed that deterioration of the specimens was more intense with $\mathrm{HCl}$ and with increase in OPTF content, after 30 days of immersion. Water absorption also increased with increase in OPTF content. Water absorption was less than $4 \%$ for concrete incorporating 3\% OPTF by volume. The requirement of ASTM (208-12) for water absorption for cellulosic building boards is 7\% [53]. The fibers could be adequate for lightweight cement composites intended for use as building boards. OPTF addition beyond 2\% however reduces workability [46].

It is reported by Ahmad et al. [53] that the trunk fibers reduced drying shrinkage and crack development in concrete. The study recommended $4 \%$ volume of fiber for the control of drying shrinkage in concrete. The density of the fiber was found to be $1100 \mathrm{~kg} / \mathrm{m}^{3}$ which agrees with the study by Wei and Meyer Ahmad [23]. OPTF was also found to help in reducing cracks at an optimum of $1 \%$ fiber volume in concrete. The study also opined that the relative high strength of the trunk fibers was due to its thick cell wall as observed in the Scanning Electron Microscopy (SEM) analysis [53]. The optimum addition by dry weight of OPTF to cement composites recommended by Abdullah et al. [83], is $2 \%$.

\subsection{Oil palm broom fiber (OPBF)}

Momoh and Dahunsi [37] presented the premiere findings on this type of oil palm fiber as there was no previously reported study on broom fibers. Oil palm broom fibers (OPBF) are the ribs of the leaflets of the oil palm tree (Figs. 1 and 3). OPBF is mainly used as sweeping brooms in many countries around the world. Compared to other oil

Table 5 Summary of chemical composition (\% weight) of OPTF

\begin{tabular}{lcccccccc}
\hline composition & \multicolumn{7}{c}{ percentage } \\
\cline { 2 - 8 } & {$[53]$} & {$[60]$} & {$[25]$} & {$[79]$} & {$[76]$} & {$[36]$} & {$[66]$} & {$[58]$} \\
\hline cellulose & - & 30.4 & 40.7 & - & 39.9 & 30.6 & - & $29-37$ \\
hemicellulose & - & 40.4 & 26.1 & - & 21.2 & 33.2 & 25.3 & $12-17$ \\
holocellulose & 72.12 & - & - & - & - & - & 76.3 & $42-45$ \\
lignin & 23.03 & 21.7 & 26.2 & 15.7 & 22.6 & 28.5 & 18.1 & $18-23$ \\
ash & - & 5.8 & 1.8 & 2.9 & 1.9 & 4.1 & 1.1 & $2-3$ \\
\hline
\end{tabular}




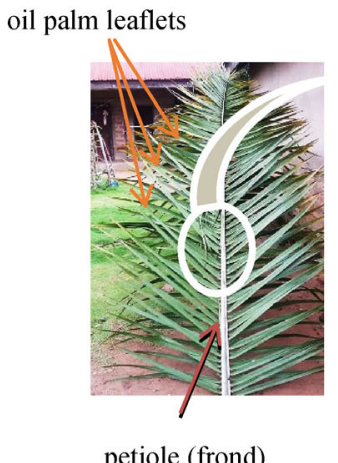

(a)

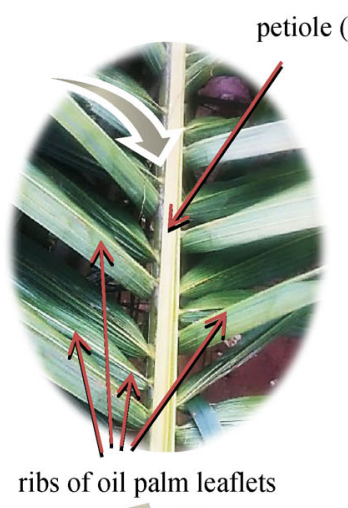

(b)

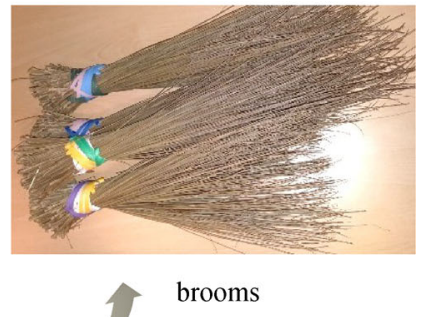

(c)

Fig. 3 Illustration of OPBF: (a) oil palm leaf; (b) magnified image of oil palm leaf; (c) OPBF tied into broom units.

palm fibers, they are larger in size with average diameter ranging between 1.5 to $2.5 \mathrm{~mm}$ with a length of between 500 and $800 \mathrm{~mm}$. Figure 3 illustrates the location of OPBF on the oil palm leaflets.

\subsubsection{Extraction}

In the rural areas of Nigeria, oil palm leaves are harvested for making sheds and roofs of mud houses or for the extraction of the ribs of the leaflets. The leaflets are first detached from the petioles after which the leaves are peeled off from the ribs of the leaflets (see Fig. 3). This extraction process is done manually with the aid of a machete or knife. The broom fibers with tensile strength in excess of $1000 \mathrm{MPa}$ are then tied into broom units only to be sold at local markets [37].

Nwankwojike et al. [84] designed, developed, and patented a palm frond broom peeling machine in a bid to reduce attendant drudgery and fatigue associated with broom fiber extraction. The electric powered version of the machine extracts over 6000 broom fibers per hour with an efficiency of $88.33 \%$ while the manually-powered version produces only about 2000 broom fibers per hour with an efficiency of $91.7 \%$. Details of the machine can be found in the study. Nduka [85] in a subsequent study developed an abrasive selection model for the broom peeling machine. The model recommended an average moisture content of $6.96 \%$ for the most effective peeling of leaves from the brooms by the machine. Processing of OPBF from oil palm leaves at a large scale is hence made possible.

The cost of one broom unit in Nigeria is about USD 0.11 and contains about $150-170$ broom fibers, each of which is $700 \mathrm{~mm}$ long and $2.5 \mathrm{~mm}$ average cross sectional diameter. Therefore, to assert that a USD 0.22 worth of broom fibers can adequately reinforce a $(225 \mathrm{~mm} \times 300 \mathrm{~mm} \times$ $1200 \mathrm{~mm}$ ) lintel beam is not only reasonable but would reduce reinforcement cost by over $90 \%$. With an approximate density of $1500 \mathrm{~kg} / \mathrm{m}^{3}$, OPBF is only $20 \%$ of the density of reinforcing steel. Replacing steel bars with OPBF as main reinforcement in concrete will improve construction speed and reduce labor cost as the result of the light weight of the resulting concrete.

\subsubsection{Chemical composition}

As far as the authors are aware, there is no study yet on the chemical composition of the broom fibers. In a related study however, the suitability of $1.13 \mathrm{~mm}$ long oil palm leaves fibers for paper-based products was investigated [86]. The report presented the following chemical composition for leaf fibers: cellulose (43.8\%), lignin $(19.7 \%)$, and hemicellulose $(36.4 \%)$. There was no mention of the broom fibers in the study. On incorporation of OPBF in cement composites, the method of improving the durability of bamboo fibers used by Terai and Minami [87] can be adopted. This includes the use of a synthetic resin and synthetic rubber for water-proofing of bamboo fiber surface to avoid water absorption in order to maintain the bond between the bamboo and concrete matrix. Agarwal et al. [6], used a similar approach by coating bamboo strips with polymeric adhesives before inserting them in concrete columns as reinforcements.

\subsubsection{OPBF in cement-based composites}

The suitability of OPBF in laterite-based roof tiles with ordinary Portland cement as binder was investigated by Momoh and Dahunsi [37]. Instead of randomly dispersing the fibers in the (cement-laterite) matrix as is the case with all other studies, the fibers were fabricated in the form of meshes of varying gauge sizes (of 10, 20,30,40, and $50 \mathrm{~mm}$ ), embedded as reinforcements in $300 \mathrm{~mm} \times$ $150 \mathrm{~mm} \times 12 \mathrm{~mm}$ laterite-cement matrices, and cured for 28 days. It should be noted that the broom fibers were not 
exposed to any form of treatment. All specimens reinforced with the fibers showed increase in flexural strength (up to 130\%). The $10 \mathrm{~mm}$ mesh size with a calculated fiber volume of $5 \%$ of the volume of a roofing tile was chosen as optimum. The study [37], also reported the tensile strength of the broom fibers as between 1010 and $1230 \mathrm{MPa}$ and elastic modulus between 73 and $104 \mathrm{GPa}$ which makes it the stiffest natural fiber yet studied. With these mechanical properties of OPBF, there are prospects of using it for concrete elements. The authors are presently investigating methods of joining the fibers to achieve lengths longer than its natural length. This is such that the fibers can be grouped together in the form of tendons and used as main reinforcements for concrete elements.

\subsubsection{Fiber treatments/enhancements}

Although no treatment for OPBF has been reported in literature, the treatment methods reported by Agarwal et al. [6] and Javadian et al. [33], can be used for OPBFreinforced concrete. Agarwal et al. [6], coated bamboo strips with different types of polymeric adhesives before inserting them in concrete as reinforcements in order to enhance bond strength. Test results recommended the "sikadur 32 gel" adhesive treatment. Javadian et al. [33] recommended water-based epoxy coating for bamboo strips in reinforcing concrete. Although bamboo/concrete bond strength was not improved by the treatment, it was argued that the bond strength between the fiber and surrounding alkaline matrix would be maintained as a result of the protection offered by the epoxy coating.

\subsection{Oil palm frond fibers (OPFF)}

Oil palm frond fibers (OPFF) originate from the petioles (fronds) of the oil palm leaves which is usually sought after to feed livestock or are left to rot away in palm plantations as manure or as erosion cover [58]. While Abdul Khalil et al. [58] reported that about 24 million tonnes of oil palm fronds are left to be discarded from oil palm factories every year in Malaysia, Kelly-Yong et al. [60], reports the frond wastes as 10.88 tonnes per hectare per year. Either of the values represents significant amount of waste which if employed in construction will attract the typical benefits of a natural fiber.

\subsubsection{Extraction}

The palm fronds are obtained by manual cutting from oil palm trees, using machete or cutlass. They are pruned in same manner, loaded into a decorticator and subjected to dew retting. The fibers are then separated manually for drying and further processing [45]. Hashima et al. [25], used the fronds for fermentable sugar production. After harvesting the fronds, they were pressed by a sugar machine, thereby removing its juice. They were dried for 3 days, shredded in pieces and sieved into particle sizes of less than $2 \mathrm{~mm}$. This method destroyed the fibers and may not be advised if the mechanical properties of OPFF are sought. The study by Puspasari et al. [88] also used the crushing method for the fronds but with a mechanical crusher (Cheso Cresher Model LCT 10 HP).

\subsubsection{Chemical properties}

There is high variation in the chemical properties of OPFF reported in literature. Factors responsible for this include, age of fibers, soil condition, climate, geography and extraction procedure [25]. Again, the review by Abdul Khalil et al. [58] attempted to set the value of chemical constituents reported by previous studies in a range. However, the values reported by Shibata et al. [36] and Bahari [66] were outside the set range. Table 6 presents the range of chemical composition of OPFF obtainable from literature.

Table 6 Summary of chemical composition of OPFF fibers from literature

\begin{tabular}{lccc}
\hline composition & \multicolumn{3}{c}{ percentage } \\
\cline { 2 - 4 } & {$[58]$} & {$[36]$} & {$[66]$} \\
\hline cellulose & $40-50$ & 39.5 & 46.6 \\
hemicellulose & $34-38$ & 29.8 & 33.9 \\
holocellulose & $80-83$ & - & 80.5 \\
lignin & $20-21$ & 23.3 & 18.3 \\
xylose & $26-29$ & - & - \\
glucose & $62-67$ & - & - \\
ash & $2-3$ & 5.7 & 2.5 \\
\hline
\end{tabular}

\subsubsection{Fiber treatments/enhancements}

Puspasari et al. [88], from their study on the drying characteristics of OPFF recommended that drying of the fronds (to below $10 \%$ moisture content) was necessary to prevent fungal attack. Shinoj et al. [24], recommended alkali treatment (also known as mercerization) if fibermatrix bonding was desirable for the composite.

The study by Hashima et al. [25] explains that increase in cellulose after alkali treatment is due to distortions to the cell wall and the resulting exposure of the cellulose. Increase in cellulose after alkali treatment also led to partial removal of hemicellulose and lignin, due to the disruption of the outer layer of the fibers.

Machaka et al. [27], suggested optimum treatment of fan palm fibers by immersion of the fibers in $4 \% \mathrm{NaOH}$ solution for $24 \mathrm{~h}$ after which the fibers are then immersed 
in distilled water for one hour to remove any residual $\mathrm{NaOH}$. They are dried and stored in plastic bags to protect them from environmental moisture.

\section{Summary and future research outlook}

\subsection{Workability}

From the review of available literature on the incorporation of OPF in cement composites, workability reduces with an increase in fiber content $[16,17,28,43,46,53]$. The study by Mazlan and Awal [81] and Musa et al. [74] attributed this to the increase in the surface area of the fiber aggregates and high-water absorption of the fibers making less water available for the mix. A possible implication of this is that the longer the mixing and transportation time of the concrete mix, the less workable it becomes as a result of fiber water absorption. The workability of a mix apart from being a function of its water-cement ratio, affects the compressive strength of the hardened concrete. Therefore, a study of the relationship between the time-rate of water absorption of OPF and water-cement ratio on the mechanical properties of cement composites incorporating the natural vegetative fibers is a possible research area.

\subsection{Setting time}

The setting time of the OPF-cement composites increases with increase in amount of OPF due to the presence of water-soluble compounds (e.g., pectin), in the fibers. This compound dissolves on contact with water in the fresh cement matrix and fastens to calcium ions, thereby inhibiting hydration through the prevention of C-S-H structure formation [89]. This explanation contradicts Ozerkan et al. [28] who reported that rapid water absorption of fibers makes less water available to the cement and aggregates thereby decreasing the setting time. Again, an in-depth study of the effect of time-dependent fiber-water absorption on initial cement hydration reaction in OPF cement composites is necessary. Such study would recommend optimum water-cement ratios and mixing times for OPF-cement mixes.

\subsection{Chemical composition}

From Table 7, it can be seen that EFBF contain the highest amount of cellulose, which by implication represents better strength. As a consequence, it has enjoyed more research attention than any other type of OPFs. The range of chemical composition of oil palm fibers from the studies reviewed is presented in Table 7.

Table 7 Summary of chemical composition of oil palm fibers

\begin{tabular}{lccc}
\hline composition & EFBF & OPFF & OPTF \\
\hline cellulose & $38-65$ & $40-50$ & $29-47$ \\
hemicellulose & $17-35$ & $30-38$ & $12-40$ \\
holocellulose & $65-86$ & $80-83$ & $42-76$ \\
lignin & $13-59$ & $18-23$ & $18-29$ \\
ash & $1-6$ & $2-6$ & $1-6$ \\
\hline
\end{tabular}

The flow chart in Fig. 4 is recommended by Shibata et al. [36] for the determination of chemical composition of the various parts of the oil palm.

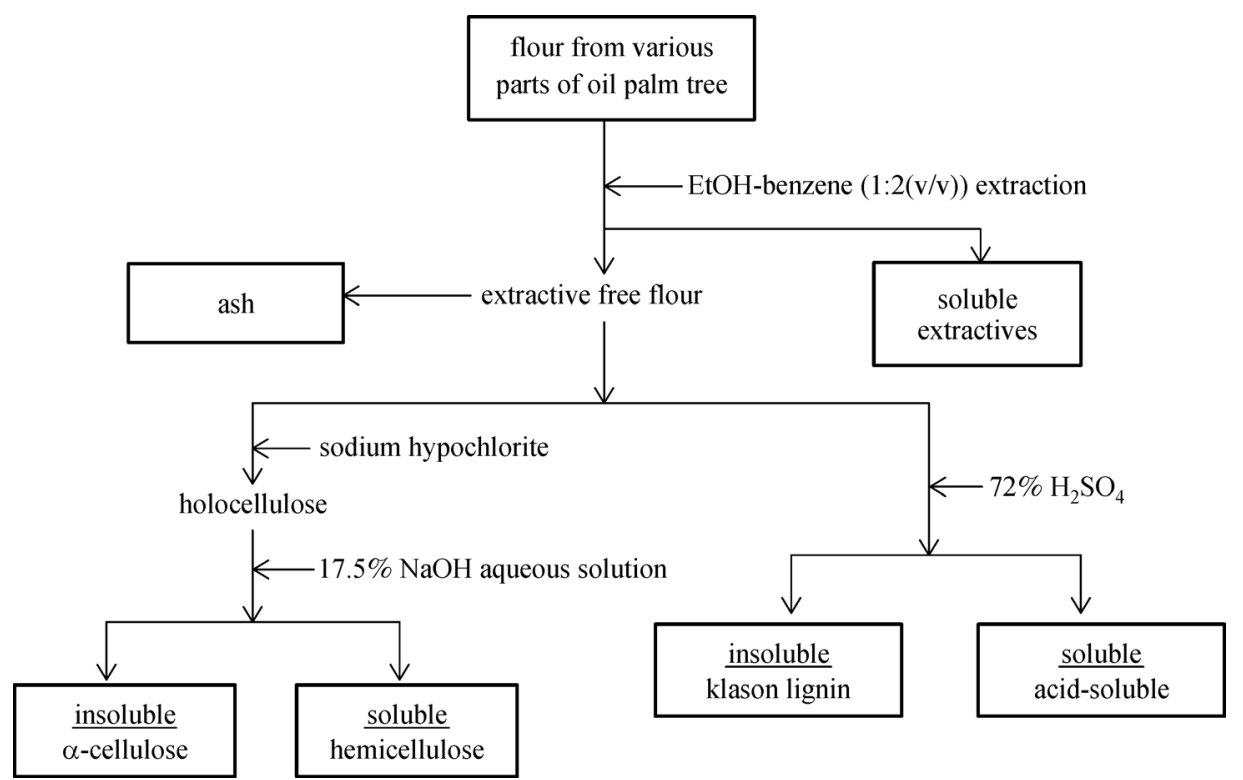

Fig. 4 A flowchart for the chemical composition analysis of various parts of oil palm (Source: Saka et al. [76]). 
Future research should be geared toward providing reliable data by correlating factors such as fiber age, chemical composition and fiber moisture content on the physical and mechanical properties of OPF.

\subsection{Treatment of oil palm fibers}

Although Pacheco-Torgal and Jalali [89] reported that the strength of natural fibers can be improved by a factor of three through pyrolisis process, silane and alkali treatments were recorded as the most effective for enhancing the strength and thermal stability of OPF $[27,43]$. On contact with $\mathrm{OPF}, \mathrm{NaOH}$ solution dissolves impurities on fiber surface and a rough surface topography is created. EFBF can lose up to $22 \%$ of initial weight if exposed to $\mathrm{NaOH}$ concentrations greater than 5\%. However, the resulting fiber surface roughness is desirable for good composite bonding. In general, all treatments improved fiber mechanical properties.

Majority of the studies agree that alkali $(\mathrm{NaOH})$ treatment is most-preferred for OPF, however, they all have varying recommendations on the optimum concentration of the alkali solution. While Sreekala et al. [44] recommended that the fibers be soaked in $5 \% \mathrm{NaOH}$ for $48 \mathrm{~h}$; Machaka et al. [27] prescribed $4 \% \mathrm{NaOH}$ for $24 \mathrm{~h}$. Norul Izani et al. [68] on the other hand prescribed $2 \%$ $\mathrm{NaOH}$ for 30 min while Ozerkan et al. [28] recommended a different alkali (i.e., $0.173 \% \mathrm{Ca}(\mathrm{OH})_{2}$ for $1 \mathrm{~h}$ ) with subsequent drying of the fibers at $60^{\circ} \mathrm{C}$ for $3 \mathrm{~h}$. A study along the lines of recommending standard alkali treatment procedure for each OPF is necessary.

\subsection{Thermal degradation}

The result of EFBF fiber degradation with respect to temperature reported by Sreekala et al. [44], reveals a polynomial trend. The trend can also be seen to be similar for all treatments as displayed in Fig. 5. A graph was plotted from the data in Table 2 and the resulting trend was divided into three zones. Each zone can be represented by a linear relationship; as shown in Eq. (1).

$$
W L=a T+C,
$$

where $\alpha$ is the slope of the linear model, $T$ is the temperature in degree Celsius, and $C$ is the weight loss $(W L)$ at $0^{\circ} \mathrm{C}$.

Zone 1 represents the temperature range between $100^{\circ} \mathrm{C}-300^{\circ} \mathrm{C}$, zone 2 is the temperature between $300^{\circ} \mathrm{C}$ and $345^{\circ} \mathrm{C}$ and zone 3 is the temperature between $345^{\circ} \mathrm{C}$ and $500^{\circ} \mathrm{C}$. Each zone of the untreated OPFs was fitted onto a linear model which can be used to estimate the OBFs' response to elevated temperature, using the coefficients in Table 8 .

A more detailed study is needed to establish the

Table 8 Coefficients for predicting temperature-dependent weight loss in $\mathrm{OPF}$

\begin{tabular}{lcccc}
\hline zone & temperature range $\left({ }^{\circ} \mathrm{C}\right)$ & $a$ & $C$ & $\begin{array}{c}\text { coefficient of determina- } \\
\text { tion }\left(R^{2}\right)\end{array}$ \\
\hline 1 & $100-300$ & 0.1463 & -15 & 0.9010 \\
2 & $300-345$ & 0.7516 & -196.54 & 0.8644 \\
3 & $345-470$ & 0.3119 & -45 & 0.8298 \\
\hline
\end{tabular}

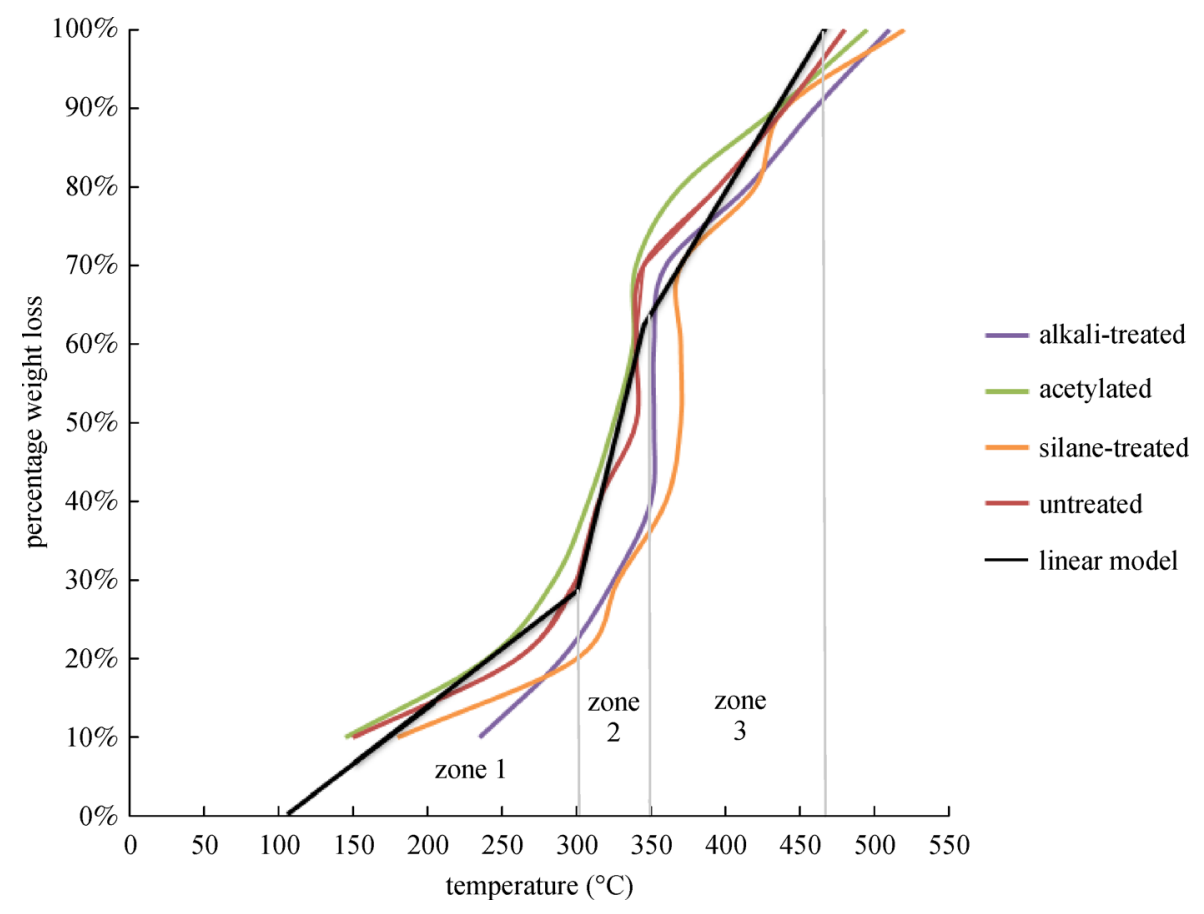

Fig. 5 Relationship between temperature $(T)$ and percentage weight loss $(W L)$ of EFBF. 
observed trend and also to correlate temperature, fiber weight-loss and tensile strength.

\subsection{Strength in cement composites}

Mazlan and Abdul Awal [81], sets the limit of inclusion of oil palm trunk fibers in cement mortars to $3 \%$ by volume with $16 \%$ and $70 \%$ increase in compressive strength and splitting tensile strength respectively. Mahat et al. [80] and Ismail and Yaacob [11] agreed with 3\% threshold of OBFs since strength reductions are likely beyond this amount. Apart from Momoh and Dahunsi [37] who reported an optimum OPBF inclusion of $5 \%$ by volume, most studies recommend 3\% volume of OPFs. Although the chemical composition for OPBF is unavailable at the moment, it is reported to be the stiffest of the oil palm fibers with tensile strength and Young's modulus in the range of 1000 $1200 \mathrm{MPa}$ and 70-100 GPa, respectively [37]. A study of the suitability of reinforcing concrete with OPBF in the form of longitudinal reinforcement tendons is a prospective research area.

Natural fiberreinforced concrete is a lightweight composite due to the light weightiness of the natural fibers. Its relative low cost also implies significant savings in the total cost of the structure. For developing countries in seismic zones, this type of composite can also be beneficial as the inertial forces generated during earthquake ground vibrations are proportional to the mass of the buildings.

Discrepancies in the values of chemical and mechanical properties of oil palm fibers reported in literature could be due to factors such as age of the fiber source, varying experimental techniques, level of expertise, varying fiber sources, fiber treatments and age of the source plant. Development of a standard characterization guideline for oil palm fibers requires attention.

The extraction, processing and provision of fibers from oil palm biomass for incorporation in cement composites could create jobs which were hitherto non-existent, environmental conservation will be enhanced and construction cost would reduce.

\section{Conclusions}

From this review, the following conclusions can been made:

1) Inclusion of oil palm fibers in cement composites reduces workability of fresh cement mixtures.

2) Oil palm fibers require treatment prior to their inclusion in cement composites.

3) Alkali-treatment is the most preferred for enhancing the mechanical properties of oil palm fibers.

4) Thermal degradation of OPF becomes rapid beyond $300^{\circ} \mathrm{C}$.

5) Percentage inclusion of OPF in cement composites at between $1 \%$ and $3 \%$ (by volume) improves the properties of cement mortars and concrete.

6) Fiber lengths should not be greater than $50 \mathrm{~mm}$ since longer lengths create "balling" of the fibers in cement mixes.

7) OPBF is the stiffest among oil palm fibers but has received almost no research attention.

8) Good quality oil palm fibers can be obtained from trees over 25 years of age.

9) Cement-based applications where OPF can be used as short discrete fiberreinforcement include, roofing tiles, building bricks, lintel beams, building claddings and facades.

10) Discrepancies in reported fiber properties, fiber treatment methods and reported enhancements makes the making of sound engineering decisions difficult when dealing with oil palm fibers.

Finally, processing of OPFs for incorporation in concrete is environmentally sustainable and cheap. It can lead to reduction in construction cost and time and provide employment opportunities.

Acknowledgements This project was funded by the Petroleum Technology Development Fund (PTDF) of Nigeria (No. PTDF/ED/PHD/MEO/1057/17).

Open Access This article is licensed under a Creative Commons Attribution 4.0 International License, which permits use, sharing, adaptation, distribution and reproduction in any medium or format, as long as you give appropriate credit to the original author(s) and the source, provide a link to the Creative Commons licence, and indicate if changes were made.

The images or other third party material in this article are included in the article's Creative Commons licence, unless indicated otherwise in a credit line to the material. If material is not included in the article's Creative Commons licence and your intended use is not permitted by statutory regulation or exceeds the permitted use, you will need to obtain permission directly from the copyright holder.

To view a copy of this licence, visit http://creativecommons.org/licenses/ by $/ 4.0 /$.

\section{References}

1. Balasubramanian J C, Selvan S S. Experimental investigation of natural fiber reinforced concrete in construction industry. International Research Journal of Engineering and Technology, 2015, 2(1): 179-182

2. Ardanuy M, Claramunt J, Toledo Filho R D. Cellulosic fiber reinforced cement-based composites: A review of recent research. Construction \& Building Materials, 2015, 79: 115-128

3. Colorado H A, Loaiza A. Portland cement paste blended with pulverized coconut fibers. Advances in Materials Science for Environmental and Energy Technologies, 2018, 6: 77-84

4. Ramakrishna G, Sundararajan T. Impact strength of a few natural fibre reinforced cement mortar slabs: A comparative study. Cement and Concrete Composites, 2005, 27(5): 547-553

5. Elenga R G, Dirras G F, Goma Maniongui J, Djemia P, Biget M P. On the microstructure and physical properties of untreated raffia textilis fiber. Composites. Part A, Applied Science and Manufacturing, 2009, 40(4): 418-422 
6. Agarwal A, Nanda B, Maity D. Experimental investigation on chemically treated bamboo reinforced concrete beams and columns. Construction \& Building Materials, 2014, 71: 610-617

7. Oladele I O, Omotoyinbo J A, Adewara J O T. Investigating the effect of chemical treatment on the constituents and tensile properties of sisal fibre. Journal of Minerals and Minerals Characterisation and Engineering, 2010, 9(6): 569-582

8. Asim M, Abdan K, Jawaid M, Nasir M, Dashtizadeh Z, Ishak M R, Hoque M E. A review on pineapple leaves fibre and its composites. International Journal of Polymer Science, 2015, 2015: 1-16

9. Agopyan A, Savastano H J Jr, John V M, Cincotto M A. Developments on vegetable fibre-cement based materials in Sao Paulo, Brazil: An overview. Cement and Concrete Composites, 2005, 27(5): 527-536

10. Claramunt J, Fernández-Carrasco L J, Ventura H, Ardanuy M. Natural fiber nonwoven reinforced cement composites as sustainable. Construction \& Building Materials, 2016, 115: 230-239

11. Ismail S, Yaacob Z. Properties of laterite bricks reinforced with oil palm empty fruit bunch fibres. Pertanika Journal of Science \& Technology, 2011, 19(1): 22-43

12. Chan C M. Effect of natural fibres inclusion in clay bricks: Physicomechanical properties. International Journal of Civil and Environmental Engineering, 2011, 5(1): 7-13

13. Sethunarayanan R, Chockalingam S, Ramanathan R. Natural fiber reinforced concrete. In: International Symposium on recent Developments in Concrete Fiber Composites. Washington D. C.: Transportation Research Board, 1989

14. Aziz M A, Paramasivam P, Lee S L. Prospects for natural fibre reinforced concretes in construction. International Journal of Cement Composites and Lightweight Concrete, 1981, 3(2): 123132

15. Al-Oraimi S K, Seibi A C. Mechanical characterisation and impact behaviour of concrete reinforced with natural fibres. Composite Structures, 1995, 32(1-4): 165-171

16. Olaoye R A, Oluremi J R, Ajamu S O. The use of fibre waste as complement in concrete in concrete for a sustainable environment. Innovative Systems Design and Engineering, 2013, 4(9): 91-97

17. Benmansour N, Agoudjil B, Gherabli A, Kareche A, Boudenne A. Thermal and mechanical performance of natural mortar reinforced with date palm fibers for use as insulating materials in buildings. Energy and Building, 2014, 81: 98-104

18. Page J, Khadraoui F, Boutouil M, Gomina M. Multi-physical properties of a structural concrete incorporating short flax fibers. Construction \& Building Materials, 2017, 140: 344-353

19. Onuaguluchi O, Banthia N. Plant-based natural fibre reinforced cement composites: A review. Cement and Concrete Composites, 2016, 68: 96-108

20. Teo D C L, Mannan M A, Kurian J V. Flexural behaviour of reinforced lightweight concrete beams made with oil palm shell (OPS). Journal of Advanced Concrete Technology, 2006, 4(3): 459468

21. Salau M A, Adegbite I, Ikponmwosa E E. Characteristic strength of concrete column reinforced with bamboo strips. Journal of Sustainable Development, 2011, 5(1): 133-143

22. Snoeck D, Smetryns P A, De Belie N. Improved multiple cracking and autogeneous healing in cementitious materials by means of chemically-treated natural fibres. Biosystems Engineering, 2015, 139: 87-99

23. Wei J, Meyer C. Improving degradation resistance of sisal fiber in concrete through fiber surface treatment. Applied Surface Science, 2014, 289: 511-523

24. Shinoj S, Visvanathan R, Panigrahi S, Kochubabu M. Oil palm fiber (OPF) and its composites: A review. Industrial Crops and Products, 2011, 33(1): 7-22

25. Hashima F S, Yussof H W, Moh'd M A K, Zaharia R A R, Illiash R M. Physiochemical and morphological characterisation of the native and alkaline pre-treated fiber pressed oil palm frond for fermentable sugars production. Chemical Engineering Transactions, 2017, 56: 1087-1092

26. Patel J P, Parsania P H. Characterization, testing, and reinforcing materials of biodegradable composites. In: Woodhead Publishing Series in Composites Science and Engineering. Cambridge: Woodhead Publishing, 2018, 55-79

27. Machaka M, Basha H, Chakra H A, Elkordi A. Alkali treatment of fan palm natural fibers for use in fiber reinforced concrete. European Scientific Journal, 2014, 10(12): 186-195

28. Ozerkan N G, Ahsan B, Mansour S, Iyengar S R. Mechanical performance and durability of treated palm fiber reinforced mortars. International Journal of Sustainable Built Environment, 2013, 2(2): $131-142$

29. Westland J A, O'Callaghan D J. U. S. Patent No. 8,435,345. 2013

30. Weerawarna S A, O'Callaghan D J. U. S. Patent No. 9,056,792. 2015

31. Lertwattanaruk P S A, Suntijitto A. Properties of natural fiber cement materials containing coconut coir and oil palm fibers for residential building applications. Construction \& Building Materials, 2015, 94(1): 664-669

32. Coutts R S. A review of Australian research into natural fiber cement composites. Cement and Concrete Composites, 2005, 27(5): 518526

33. Javadian A, Wielopolski M, Smith I F, Hebel D E. Bond-behaviour study of newly developed bamboo-composite reinforcement in concrete. Construction \& Building Materials, 2016, 122: 110-117

34. Abu A K, Yalley P P K, Adogla F. The use of raffia palm (raffia hookeri) piassava fibers as reinforcement of concrete. International Journal of Engineering Science, 2016, 5(6): 1-6

35. Food and Agriculture Oganization. World Agriculture: Towards 2030/2050 - Interim Report. Rome: FAO, 2006

36. Shibata M, Varman M, Tono Y, Miyafuji H, Saka S. Characterisation in chemical composition of of the oil palm (Elaeis guineensis). Journal of the Japan Institute of Energy, 2008, 87(5): 383-388

37. Momoh E O, Dahunsi B I. Suitability of oil-palm-broom-fibres as reinforcement for laterite-based roof tiles. International Journal of Software \& Hardware Research in Engineering, 2017, 5(4): 27-35

38. Taiwo O F A W, Alkarkhi A F, Ghazali A, Wan Daud W. Optimization of the strength properties of waste oil palm (Elaeis guineensis) fronds fiber. Journal of Natural Fibers, 2017, 14(4): 551-563

39. Obilade I O, Olutoge F A. Flexural characteristics of oil palm stem reinforced concrete beams. Journal of Engineering and Applied Sciences (Asian Research Publishing Network), 2013, 5(3): 21-25 40. Shareef E T D, Ramli M B. Study on the effect of using palm fiber 
on the properties of high strength flowable mortar. In: The 34th Conference on Our World in Concrete \& Structures. Singapore: CIPremier, 2009

41. Kaliwon J, Ahmad S S, Aziz A A. Performance of oil palm EFB fibre reinforced concrete roof slates. In: International Conference on Science and Social Science Research (CSSR). Kuala Lumpur, 2010

42. Ofuyatan O, Olutoge F. Flexural characteristics and potentials of oil palm stem as reinforcement in concrete beams. Journal of Emerging Trends in Engineering and Applied Sciences, 2013, 4(4): 642-647

43. Or K H, Putra A, Selamat M Z. Oil palm empty fruit bunch fibers as sustainable acoustic absorber. Applied Acoustics, 2017, 119: 9-16

44. Sreekala M S, Kumaran M G, Thomas S. Oil palm fibers: Morphology, chemical composition, surface modification, and mechanical properties. Journal of Applied Polymer Science, 1997, 66(5): 821-835

45. Danso H. Properties of coconut, oil palm and bagasse fibres: As potential building materials. In: The 3rd International Conference on Natural Fibers: Advanced Materials for a Greener World. Braga: Procedia Engineering, 2017

46. Ahmad Z, Saman H M, Tahir F M. Mechanical properties of oil palm trunk fibre reinforced concrete. In: The 26th Conference on Our World in Concrete \& Structure. Singapore: CI-Premier, 2001

47. Zulkifli R, Nor M J M, Ismail A R, Nuawi M Z, Abdullah S, Tahir M F M, AbRahman M N. Comparison of acoustic properties between coir fibre and oil palm fibre. European Journal of Scientific Research, 2009, 33(1): 144-152

48. Yalley P P, Kwan A S K. Use of coconut fiber as an enhancement of concrete. Journal of Engineering Technology, 2009, 3: 54-73

49. Yahaghi J, Muda Z C, Beddu S B. Impact resistance of oil palm shells concrete reinforced with polypropylene fiber. Construction \& Building Materials, 2016, 123: 394-403

50. Muda Z C, Malik G, Usman F, Beddu S, Alam M A, Mustapha K N, Birima A H, Zarroq O S, Sidek, L M, Rashid M A. Impact resistance of sustainable construction material using light weight oil palm shells reinforced geogrid concrete slab. In: IOP Conference Series: Earth and Environmental Science, 16(1), IOP Publishing, 2013

51. Poh-Yap S, Johnson-Alengaram U, Hung-Mo K, Zamin-Jumaat M. High strength oil palm shell concrete beams reinforced with steel fibers. Materiales de Construcción, 2017, 67(328): 142-152

52. Mayowa I C, Chinwuba A. Effects of oil palm fibre on the compressive strength of mortar. Journal of Emerging Trends in Engineering and Applied Sciences, 2013, 4(5): 714-716

53. Ahmad Z, Saman H M, Tahir P M. Oil palm trunk fiber as a biowaste resource for concrete reinforcement. International Journal of Mechanical and Materials Engineering, 2010, 5(2): 199-207

54. Ahmad M H, Nurazuwa M N. Mix design of palm oil fiber concrete. In: International Conference on Civil Engineering (ICCE08). Pahang: Universiti tun Hussein onn Malaysia, 2008

55. Poornima J, Sivaraja M. Rehabilitation of RC beams using natural fiber (Jute) reinforced polymer composites. Journal of Intelligent \& Fuzzy Systems, 2015, 28(1): 311-316

56. Mo K H, Visintin P, Alengaram U J, Jumaat M Z. Prediction of the structural behaviour of oil palm shell lightweight concrete beams. Construction \& Building Materials, 2016, 102: 722-732

57. Dungani R, Jawaid M, Khalil H P S A, Jasni J, Aprilia S, Hakeem K $\mathrm{R}$, Hartati S, Islam M N. A review on quality enhancement of oil palm trunk waste by resin impregnation: Future materials. BioResources, 2013, 8(2): 3136-3156

58. Abdul Khalil H P S, Jawaid M, Hassan M T, Paridah A Z. Oil palm biomass fibres and recent advancement in oil palm biomass fibres based hybrid biocomposites. In: Composites and Their Applications. London: IntechOpen, 2012, 187-220

59. Nadlene R, Sapuan S M, Jawaid M, Ishak M R, Yusriah L. A review on roselle fiber and its composites. Journal of Natural Fibers, 2016, 13(1): 10-41

60. Kelly-Yong T L, Lee K T, Mohamed A R, Bhatia S. Potential of hydrogen from oil palm biomass as a source of renewable energy worldwide. Energy Policy, 2007, 35(11): 5692-5701

61. Sreekala M S, Kumaran M G, Joseph S, Jacob M, Thomas S. Oil palm fibre reinforced phenol formaldehyde composites: Influence of fibre surface modifications on the mechanical performance. Applied Composite Materials, 2000, 7(5/6): 295-329

62. Sreekala M S, George J, Kumaran M G, Thomas S. The mechanical performance of hybrid phenol-formaldehyde-based composites reinforced with glass and oil palm fibres. Composites Science and Technology, 2002, 62(3): 339-353

63. Jacob M, Thomas S, Varughese K T. Mechanical properties of sisal/ oil palm hybrid fiber reinforced natural rubber composites. Composites Science and Technology, 2004, 64(7-8): 955-965

64. Agrawal R, Saxena N S, Sharma K B, Thomas S, Sreekala M S. Activation energy and crystallization kinetics of untreated and treated oil palm fiber reinforced phenol formaldehyde composites. Materials Science and Engineering A, 2000, 277(1-2): 77-82

65. Jayashree E, Mandal P K, Madhava M, Kamraj A, Sireesha K. Development of a decorticator for extraction of quality fiber from oil palm empty fruit bunches. In: The 15th Plantation Crops Symposium Placrosym XV. Mysore: Central Coffee Research Institute, 2002

66. Bahari M A M. Oil palm trunk (OPT) as an alternative cellulosic material for brown paper production. Thesis for the Master's Degree. Pekan Pahang: Universiti Malaysia Pahang, 2010

67. Koba Y, Ishizaki A. Chemical composition of palm fiber and its feasibility as cellulosic raw material for sugar production. Agricultural and Biological Chemistry, 1990, 54(2): 1183-1187

68. Norul Izani M A, Paridah M T, Anwar U M K, Mohd Nor M Y, H'ng P S. Effects of fiber treatment on morphology, tensile and thermogravimetric analysis of oil palm empty fruit bunches fibers. Composites. Part B, Engineering, 2013, 45(1): 1251-1257

69. Fatra W, Sanjaya R, Zulfansyah Z, Rionaldo H, Helwani Z. Alkaline treatment of oil palm frond fibers by using extract of oil palm EFB ash for better adhesion toward polymeric matrix. Journal of Engineering and Technological Sciences, 2015, 47(5): 498-507

70. Nishiyama Y, Okano T. Morphological changes of ramie fiber during mercerization. Journal of Wood Science, 1998, 44(4): 310313

71. Beckermann G W, Pickering K L, Foreman N J. The processing, production and improvement of hemp-fibre reinforced polypropylene composite materials. In: Proceeding of the 2nd International Conference on Structure, Processing and Properties of Materials. Dharka: Bangladesh University of Engineering and Technology, 2004

72. Yousif B F. Effect of oil palm fibers volume fraction on mechanical 
properties of polyster composites. International Journal of Modern Physics, 2010, 24(23): 4459-4470

73. Ismail M A, Hashim H. Palm oil fiber concrete. In: The 3rd ACF International Conference. Ho chi minh city, 2008

74. Musa A G, Rajoria N, Mohammed A G. Effect of palm oil fiber on laterized concrete. International Journal of Engineering Technology, Management and Applied Sciences, 2017, 5(5): 686-695

75. Wahab R, W. Samsi H, Mohamed A. Utilization potential of 30 yearold oil palm trunks laminated veneer lumbers for non-structural purposes. Journal of Sustainable Development, 2009, 1(3): 109-113

76. Saka S, Munusamy M V, Shibata M, Tono Y, Miyafuji H. Chemical constituents of the different anatomical parts of the oil palm (Elaeis guineensis) for their sustainable utilization. In: JSPS-VCC Group Seminar 2008, Natural Resources and Energy Environment. Kyoto, 2008

77. Ahmad Z, Ibrahim A, Tahir P. Drying shrinkage characteristic of concrete reinforced with oil palm trunk fiber. International Journal of Engineering Science and Technology, 2010, 2(5): 1441-1450

78. Karade S R. Cement-bonded composites from lignocellulosic wastes. Construction \& Building Materials, 2010, 24(8): 1323-1330

79. Choowang R, Hiziroglu S. Properties of thermally-compresses oil palm trunks (Elaeis guineensis). Journal of Tropical Forest Science, 2015, 27(1): 39-46

80. Mahat N, Yaacob Z, Mastan N F, Abd Rashid A F, Zainordin Z, Mohamed Rashid M R, Husin H N, Khalil N, Mat Noor M N, Wan Abdullah W F I, Abd Rahman N A, Ahmad S. Comparison study on oil palm trunk and oil palm fruit bunch fiber reinforced laterite bricks. Modern Applied Science, 2010, 4(7): 119-129
81. Mazlan D, Abdul Awal A S M. Properties of cement based composites containing oil palm stem as fiber reinforcement. Malaysian Journal of Civil Engineering, 2012, 24(2): 107-117

82. Tomimura Y. Chemical characteristics and utilization of oil palm trunks. Japan Agricultural Research Quarterly, 1992, 25: 283-288

83. Abdullah A, Abdullah M M A B, Kamarudin H, Ghazali C M R, Salleh M A A M, Sang P K, Muhammad Faheem M T. Study on the properties of oil palm trunk fiber (OPTF) in cement composite. Applied Mechanics and Materials, 2013, 421: 395-400

84. Nwankwojike B N, Agunwamba J C, Onwuka O S. Design and Development of Palm Frond Broom Peeling Machine. Patent No. $\mathrm{NG} / \mathrm{P} / 2014 / 177.2014$

85. Nduka B. Development of abrasive selection model/chart for palm frond broom peeling machine design. International Journal of Engineering Research and Applications, 2014, 4(12): 84-90

86. Kassim A S M, Mohd A A, Nadiah I, Hafeez Z M, Dayang Z N F A. Oil palm leaf fibre and its suitability for paper-based products. Journal of Engineering and Applied Sciences (Asian Research Publishing Network), 2006, 11(11): 7364-7369

87. Terai M, Minami K. Research and development on bamboo reinforced concrete structure. In: Proceedings of the 15th World Conference on Earthquake Engineering, Lisbon, 2012

88. Puspasari I, Talib M Z M, Daud W R W, Tasirin S M. Characteristic drying curve of oil palm fibers. International Journal on Advanced Science, 2014, 4(1): 20-24

89. Pacheco-Torgal F, Jalali S. Cementitious building materials reinforced with vegetable fibres: A review. Construction \& Building Materials, 2010, 25(2): 575-581 